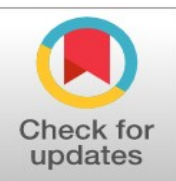

PRIMARY RESEARCH

\title{
Small rural schools on the edge of survival: Comparative assessment of stakeholders' perspectives in Latvia and Norway
}

\author{
Ilze Koroḷeva ${ }^{1}$, Inta Mieriṇa ${ }^{2 *}$, Ieva Kārkliṇa ${ }^{3}$ \\ 1, 2, 3 Institute of Philosophy and Sociology, University of Latvia, Riga, Latvia
}

\author{
Keywords \\ Rural communities \\ Local schools \\ Endogenous development \\ Community involvement \\ Received: 14 April 2016 \\ Accepted: 14 June 2017 \\ Published: 21 August 2017
}

\begin{abstract}
In the light of globalization, national education strategies in many countries consider the need to preserve their small rural schools. The study aimed to analyse the small schools' survival strategies and the attitudes towards their role in the development of rural communities. The data obtained during the comparative project "Rural Depopulation and the Governance of Education: Comparative Study of Latvia and Norway" was used. A comparative quantitative survey of municipalities, a survey of school administrations, and a set of comparative case studies carried out in rural areas of Latvia and Norway enable multi-faceted analysis of the role of small schools within different governance and education systems. The causes of school closures and the resulting problems are similar in both countries; however, the rationale and the attitude of stakeholders are significantly different.
\end{abstract}

(C) 2017 The Author(s). Published by TAF Publishing.

\section{INTRODUCTION AND LITERATURE REVIEW}

Low population density, society aging, and relatively extensive land use are the unifying elements that characterize rural areas in all European countries. In recent decades, a significant change in attitude towards the role of rural communities has taken place, as they are increasingly identified as important agents for local development. These changes in the perception stem from geopolitical and global processes, as well as from a new understanding of the importance of rural areas and their interaction with urban areas. Nowadays, representatives of rural communities are more involved in decision-making processes than before.

Two contrasting theoretical models of rural development-exogenous and endogenous-historically identify rural development policy and the role of community in development processes. The exogenous model defines the rural development as a process driven by an external influence, whereas the endogenous model holds that the territorial development is initiated from "the inside" rather than provided and nudged from the outside. The proponents of the endogenous rural development emphasize the failure of the exogenous model (such as state subsidies to conventional agriculture) to ensure rural development, as well as the developments that have taken place in the total communities. At the core of this approach are self-reliance and rural sustainability (Baldock et al., 2001). There has been a growing awareness that countryside must be socially viable and, therefore, dependent on the vitality of rural communities. Local resources (natural resources,

\footnotetext{
${ }^{*}$ Corresponding author: Inta Mierina

${ }^{\dagger}$ Email: inta.mierina@lu.lv
} 
human resources, cultural resources) should be involved in sustainable development of territory, and local initiatives and enterprises are considered to be the main driving force of the development. Great emphasis is placed on local capacity-building (skills, institutions, and infrastructure) in order to facilitate participation and prevent exclusion (Lowe et al., 1995; Long and van der Ploeg, 1994; Owusu, 2016; Shucksmith, 2000; Van der Ploeg et al., 1995).

Sociologists' view of the concept of 'endogenous development' is more related to social rather than economic growth. Local control and self-determination as well as people's rights to express their views in matters that affect their lives are important values of endogenous development. Principles of subsidiarity, equality, and capacity to build flexible communities are very important. Ray (1998) uses the term "cultural economy" to describe interaction among local and external social agents (interrelations between endogenous and exogenous forces) within processes of production and consumption (Ray, 1998). In general, such an approach to rural development is more focused on local interests and needs.

At the same time, the endogenous model is criticized for being relatively unpractical in today's Europe. Researchers emphasize that local communities can never be free from outside influence, particularly in a global world; rural areas have to interact with the urban areas and have to be affected by external forces, including government regulations. Therefore, exogenous and endogenous processes must be balanced (e.g., Ray, 2001). Sometimes, a top-down support is needed in order to facilitate bottom-up initiatives and development (Woolcock and Narayan, 2000). As a result of previously mentioned critique, Ray introduced the concept of neo-endogenous development (Ray, 2001), where significance of external factors is identified, but potential of local area to guide its development remains (see, e.g., Ray, 2000, 2001, 2006). Consequently, exogenous and endogenous development should be seen as dualism of ideal types, which flow into regional development strategies and not mutually exclusive.

In this paper, we focus on the processes in rural communities related to the closure of small rural schools, and the local mobilisation around school closure. A small school is defined as a school with fewer than 100 students. At the national level, the decision to close or keep a school is primarily motivated by economic considerations, yet policy-makers often forget the impact of the school on the local community. These schools are often at the heart of their villages' social life, yet the pedagogical and social significance and possibilities of small rural schools are largely ignored when authorities close them (Autti and Hyry-Beihammer, 2014; Teng et al., 2016). Rural schools via various activities facilitate the development and strengthening of social capital. At the same time, more organized, active, and trusting communities are more efficient in preventing the school closure, and are more likely to achieve that the school remains open (Autti and Hyry-Beihammer, 2014; Ana Belen et al., 2017).

Both Latvia and Norway are experiencing depopulation in rural areas, and the concentration of people around big cities. Accordingly, school closure is high on the agenda in both countries, and in both cases, it is a contested issue. However, there are also important differences between Latvia and Norway in terms of depopulation characteristics, population trends (population growth in Norway vs. decline in Latvia); economic conditions (financial possibilities); school and district policy; geography, and the historical context.

The perspective of various stakeholders on small local schools can only be assessed in the context of the on-going demographic changes in the communities. While Norway has high in-migration, Latvia suffers from continuous out-migration. While in Norway, the 
size of the population is increasing $(+11 \%$ in the last 10 years), in Latvia, it is decreasing $(-11 \%$ in the last 10 years). As shown by statistics, the size of the population in Latvia between 1991 and 2014 decreased by 656 thousands or 25\%, especially fast-during the last 15 years (Central Statistical Bureau (CSB), 2015). Nearly two-thirds of the population reduction are related to negative migration balance, and it is clear that it will be the determining factor affecting the future population decline in Latvia. The challenges linked to uneven development and migration have been highlighted by Marsden (2009). According to him, the main question in the context of rural development is - how rural areas and communities can respond to the challenges of increasing mobility in order to reduce vulnerability and enhance sustainability?

Emigration, in combination with low birth rates has led to depopulation, particularly in the total area of Latvia. Concentration of population around big cities (particularly around Riga) continues. Share of Riga planning regions has increased by an average of 0.3 percentage points a year, reaching $50.8 \%$ of the population at the beginning of 2015. Distinctly monocentric settlement system speeds up the depopulation of other Latvian regions, especially fast reduction of population-among rural areas. These depopulation trends significantly affect the education system and the network of educational institutions in the country. The projected number of school-age children has an increasing tendency in Norway, vs. stagnating or even decreasing projections in Latvia. The proportion of school-age children has decreased in Latvia almost two times since 2000, reaching a minimum in 2013.

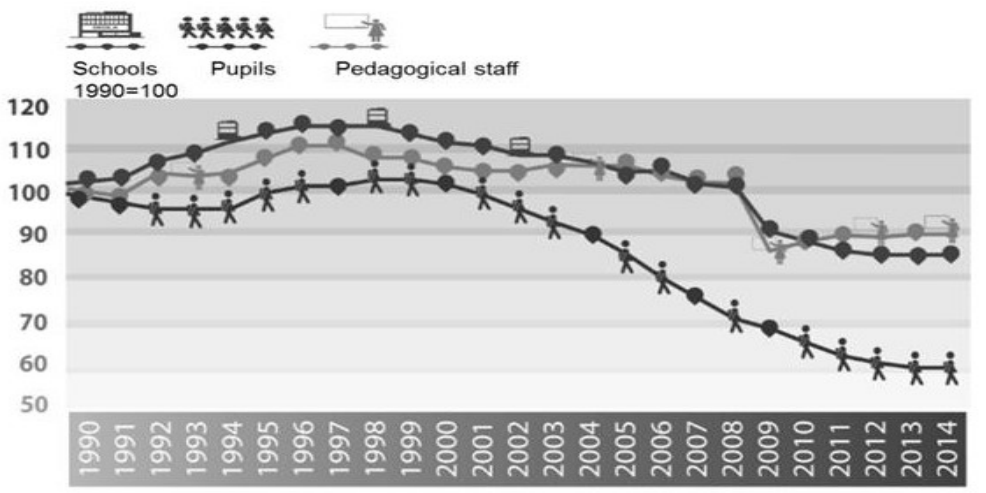

FIGURE 1. Changes in the number of schools, pupils and teachers in Latvia Source: Latvijas Sabiedriskie Mediji (LSM), (2015)

As a result of demographic and socio-economic situation, set of educational institutions in Latvia consists of schools with a small number of students. This has also led to closure of many schools, particularly during the time of the latest economic crisis. In school year $2014 / 2015$, there were 311 or $40 \%$ of all general and special education institutions in Latvia with number of students up to 100 . Approximately $84 \%$ of these "small" schools are located in rural areas. Therefore, lack of effectiveness of education expenditures and insufficient quality of education in rural schools are main arguments supporting optimization of schools in Latvia.

In the context of rural schools, it is important to understand how rural development is defined and perceived at the national level, and what the goals and aims of development are? Contrary to Norway, previous studies show that in Latvia, there is a lack of clear rural development strategy. Rural development is often understood only in relation to the traditional areas of rural economy such as agricultural production (Nagler and Naudé, 2013). 
Many studies have shown that while Norway has a high level of social capital, the level of social capital in Latvia, similar to other post-communist states, is low. People have little trust in each other and the level of community activism and associational engagement is low. The previous analysis of the engagement of communities in the processes of rural development and their opportunities to influence different local or broader processes allows to conclude that the communities in Latvia often take a passive, waiting position, or do not notice opportunities. This can be explained by various factors: lack of experience, lack of community organization or passivity, human and other resources, lack of support, lack of competence, failure to adapt, passivity, and apathy. Thus, the capacity and ability of Latvian rural communities to participate in decisions, where state and rural interests are in contrast, are limited. The closure of rural schools is one such example.

Comparing Latvia and Norway-two contrasting cases that share many of the problems yet a very different socio-economic and cultural context-allows us to test if these differences lead to different outcomes or, since processes and trends resemble, we will find a lot of similarities. The research questions we ask in this study are:

- How similar or different are the changes in the rural school network in Latvia and Norway?

- How do communities and authorities in Latvia and Norway see the role of schools and what is their attitude towards keeping or closing the small schools?

-What is the engagement of the local community in the decision-making, and has there been local mobilization around the school closures?

This study aims to contribute to our knowledge of the processes of consolidation of the rural school network in Norway and Latvia, and to offer new insights into the involvement of local communities as active agents in the decision-making concerning closure or preserving small rural schools.

\section{METHODOLOGY}

The data in this paper are based on was gathered as part of project "Rural Depopulation and the Governance of Education: Comparative Study of Latvia and Norway" funded by NFI/EEZ grant scheme and implemented by the University of Latvia and NIBR researchers. The survey of municipality representatives included: 103 respondents from local administration in Latvia and 159 in Norway. Target groups were education and/or development managers in local municipalities. The study also included a survey of small (up to 100 pupils) schools in Latvia $(n=200)$. The fieldwork took place from March till May 2016.

\section{RESULTS}

The results of the survey show that closing of schools has been very common both in Latvia and Norway (Table 1). While such possibility was discussed in more municipalities in Norway than in Latvia, when it comes to actually closing the school, Latvia has been more decisive: in $31 \%$ of municipalities in Norway, and $37 \%$ in Latvia, at least one school was closed in the last five years.

In the next two years, additional $10 \%$ municipalities in Norway and $14 \%$ in Latvia will be closing at least one school, and even more will be merging schools. It is also interesting to see that there is much more uncertainty in Latvia than in Norway-every forth municipality does not know if they will need to close or merge schools in the next two years. Such uncertainty negatively affects the ability to plan the future of schools and may delay investing in their resources. In many parishes (towns) in Latvia, there are no primary schools anymore. $37 \%$ municipalities in Latvia and 31\% in Norway expect further school closures by 2020 . In Latvia, just 38\% of small schools feel safe about their future. 
TABLE 1. Changes in the number of schools (\%)

\begin{tabular}{|c|c|c|c|}
\hline & & Latvia Municipalities & Norway Municipalities \\
\hline \multirow{3}{*}{$\begin{array}{l}\text { In your municipality, has a } \\
\text { primary school or schools } \\
\text { been closed or merged in } \\
\text { the last five years? }\end{array}$} & School/schools were closed & 37 & 31 \\
\hline & $\begin{array}{l}\text { No, but there have been } \\
\text { discussions about closures }\end{array}$ & 11 & 28 \\
\hline & No such discussions & 52 & 41 \\
\hline \multirow{5}{*}{$\begin{array}{l}\text { Does the municipality plan } \\
\text { closing primary schools in } \\
\text { the next two years? }\end{array}$} & Yes one school & 9 & 8 \\
\hline & Yes, two schools & 2 & 1 \\
\hline & Yes, three or more schools & 3 & 1 \\
\hline & No such plans & 60 & 83 \\
\hline & Difficult to say & 26 & 6 \\
\hline \multirow{4}{*}{$\begin{array}{l}\text { Does the municipality plan } \\
\text { merging primary schools in } \\
\text { the next two years? }\end{array}$} & $\begin{array}{l}\text { Yes, it is planned to merge two } \\
\text { schools }\end{array}$ & 17 & 11 \\
\hline & $\begin{array}{l}\text { Yes, it is planned to merge more } \\
\text { than two schools }\end{array}$ & 2 & 4 \\
\hline & $\begin{array}{l}\text { No, there are no plans of } \\
\text { merging schools }\end{array}$ & 59 & 79 \\
\hline & Difficult to say & 22 & 6 \\
\hline \multirow{2}{*}{$\begin{array}{l}\text { Does the municipality } \\
\text { consider opening new } \\
\text { primary schools in the next } \\
\text { two years? }\end{array}$} & Yes, one school & 6 & 4 \\
\hline & No such plans & 94 & 96 \\
\hline
\end{tabular}

The closing of schools alone does not provide a full picture of the ongoing changes with respect to rural schools. In Latvia $71 \%$ of small schools have experienced merging of classes (in 55\% it happened more than once), 81\% have experienced a decrease in number of pupils, yet just $35 \%$ have reduced the number of teachers in the last two years. Norway has introduced much more significant lay-offs of teachers (Table 2).

TABLE 2 . Changes within schools (\%)

\begin{tabular}{llll}
\hline \hline \multirow{2}{*}{ Merging of classes } & & Latvia Municipalities & Norway Municipalities \\
& Did not happen & 26 & 40 \\
& Happened in some cases & 55 & 37 \\
& Were commonplace & 20 & 23 \\
Reducing the number of & Did not happen & 44 & 28 \\
teachers & Happened in some cases & 53 & 54 \\
& Were commonplace & 2 & 18 \\
\hline \hline
\end{tabular}

When asked about attitudes towards mergers of classes or closures of small rural schools, majority of schools and municipalities in Latvia tend to agree or agree that these should be avoided. $39 \%$ of municipalities and almost two thirds $64 \%$ of small rural schools in Latvia fully agree that the municipality should do everything possible to maintain such schools. Interestingly, in Norway, attitudes are much more diverse. In fact, majority of municipality representatives tend to disagree or disagree that the municipality should do everything possible to avoid closures of small rural schools. Only $6 \%$ fully agree with this statement (Table 3). 
TABLE 3 . Attitudes towards closures of small rural schools and mergers of classes (\%)

\begin{tabular}{lllll}
\hline \hline & & Latvia Municipalities & Norway Municipalities & Schools in Latvia \\
\hline Schools should seek to & Fully disagree & 1 & 18 & 1 \\
avoid merger of classes & Tend to disagree & 15 & 39 & 6 \\
& Tend to agree & 41 & 27 & 37 \\
& Fully agree & 43 & 16 & 56 \\
The municipality should do & Fully disagree & 2 & 41 & 1 \\
everything possible to & Tend to disagree & 17 & 39 & 6 \\
maintain small rural & Tend to agree & 42 & 13 & 29 \\
schools & Fully agree & 39 & 6 & 64 \\
\hline \hline
\end{tabular}

The most important argument for closing the schools is, obviously, the small number of pupils. In Latvia, in the economic argument is particularly important. However, there are also differences in the perception of small schools. In Norway, support for closing or merging of small schools is related to the opinion held by the majority of municipality representatives that a bigger school provides a better learning and social environment for the pupils, whereas in Latvian municipalities, the dominant opinion is that, on contrary, a smaller school provides a better social environment for the pupils, and that the teachers at small schools have more opportunities to provide individual support to each pupil. The survey of school administrators in Latvia shows that a positive opinion about small rural schools is especially widespread among the representatives of such schools themselves: $73 \%$ are fully convinced that teachers at small schools have more opportunities to provide individual support to each pupil and $64 \%$ are sure that a small school provides a better social environment. This opinion is not shared by most Norwegian respondents (Tables available upon request). Another concern, especially prevalent in Latvia, is the travel time. Transportation is a problem in $25 \%$ municipalities in Norway and $30 \%$ - in Latvia.

TABLE 4. The use of school facilities during off-school hours for activities that are not provided directly by the school (\%)

\begin{tabular}{lll}
\hline \hline & Latvia Municipalities & Norway Municipalities \\
\hline Private businesses such as hairdresser, dentist, lawyer, etc & 10 & 6 \\
Concerts & 32 & 48 \\
Private parties & 15 & - \\
Summer/winter camps & 67 & - \\
Sports competitions, sports clubs unrelated to the school & 69 & 73 \\
Civil society groups (leisure and hobby groups) unrelated to the school & 40 & 77 \\
Open activities for the village such as the celebration & 42 & 77 \\
of the national day, Christmas celebrations, etc. & & \\
Further education for adults & 53 & 22 \\
After school activity for pupils (SFO) & 66 & - \\
Kindergarten/preschool education & 52 & 27 \\
Other & 0 & 5 \\
No, school premises are only used for school activities & 5 & 1 \\
\hline \hline
\end{tabular}

The survey shows that the local inhabitants collaborate with the school and are also involved, at least sometimes, in the provision of school functions. For example, 52\% of municipality representatives in Norway and $42 \%$ in Latvia noted that parents and other family members are regularly involved in such activities. Local businesses and NGO's are 
also usually involved, especially in Latvia (16-17\%) of municipalities involve them regularly). No municipalities in Latvia and only $10 \%$ in Norway never involve local inhabitants in the provision of school functions (tables available upon request). It attests to how deeply embedded in local communities the schools are.

The data reveal that the concern for closing of rural schools is also linked to the perceived importance of the school for the community. As suggested by the theory, a school is not just a place of learning, but also performs other important functions in the community, often serving as a community centre. In Norway, for example, in most municipalities, school premises are used for open activities for the village such as the celebration of the national day, Christmas celebrations, etc. and activities of civil society groups (leisure and hobby groups) unrelated to the school and sports competitions, sports clubs unrelated to the school etc. Moreover, in almost half of municipalities, concerts are also organised in school premises (Table 4). In Latvia, most municipalities allow the use of school facilities for summer/winter camps, sports competitions or clubs unrelated to school, after-school activities for pupils, kindergarten/preschool education, and further education of adults. Only in a few municipalities, schools are not offering any unrelated off-school activities.

Considering the processes of depopulation and the diverse and important role of schools in rural communities, municipality representatives in Latvia, more than in Norway, are concerned that young families will not settle in small villages if there are no schools-87\% tend to agree or agree with this statement compared to 58\% in Norway (Table 5). The representatives of schools are even more convinced about it than the representatives of municipalities.

TABLE 5 . Perceived impact on the community (\%)

\begin{tabular}{|c|c|c|c|c|}
\hline & & $\begin{array}{l}\text { Latvia } \\
\text { Municipalities }\end{array}$ & $\begin{array}{l}\text { Norway } \\
\text { Municipalities }\end{array}$ & $\begin{array}{l}\text { Schools } \\
\text { in Latvia }\end{array}$ \\
\hline \multirow{8}{*}{$\begin{array}{l}\text { Young families will } \\
\text { not settle in small } \\
\text { villages if there are } \\
\text { no schools } \\
\text { How has the school } \\
\text { closure affected the } \\
\text { community? (if the } \\
\text { school was closed) }\end{array}$} & Fully disagree & 5 & 13 & 1 \\
\hline & Tend to disagree & 9 & 30 & 1 \\
\hline & Tend to agree & 36 & 38 & 25 \\
\hline & Fully agree & 51 & 20 & 73 \\
\hline & $\begin{array}{l}\text { School closure has affected the } \\
\text { local community negatively }\end{array}$ & 23 & 13 & \\
\hline & $\begin{array}{l}\text { School closure has affected the } \\
\text { local community positively }\end{array}$ & 0 & 16 & \\
\hline & $\begin{array}{l}\text { School closure has not } \\
\text { significantly affected the } \\
\text { community life }\end{array}$ & 59 & 50 & \\
\hline & Difficult to say & 18 & 21 & \\
\hline
\end{tabular}

In municipalities where a school was closed, $23 \%$ in Latvia and $13 \%$ in Norway admitted that the school closure has negatively affected the local community. Interestingly, in Norway, $16 \%$ see positive changes. One can conclude that while in Latvia, there are huge worries about the effect of school closures on the community as well as pupils, in Norway, the effect seems to be small and not always negative. We also asked our respondents, who took part in making the decision, on the fate of the school. The answers show that in both Latvia and Norway, the issue is, to a large extent, decided by local politicians and municipal administration (Table 6). 
TABLE 6. Stakeholders involved in deciding the fate of the school (\%)

\begin{tabular}{|c|c|c|c|c|c|c|c|c|}
\hline & \multicolumn{4}{|c|}{ Latvia } & \multicolumn{4}{|c|}{ Norway } \\
\hline & Did not & To Some & To a Large & DK & Did not & To Some & To a Large & DK \\
\hline & Involve & Extent & Extent & & Involve & Extent & Extent & \\
\hline a. Local politicians & 2 & 19 & 79 & & 1 & 4 & 94 & 1 \\
\hline b. Municipal administration & 9 & 21 & 70 & & 1 & 11 & 87 & 1 \\
\hline c. School directors & 5 & 35 & 61 & & 4 & 31 & 62 & 2 \\
\hline d. Teachers & 5 & 35 & 61 & & 9 & 47 & 42 & 2 \\
\hline e. Parents and parents' organisations & 7 & 28 & 63 & 2 & 4 & 30 & 63 & 2 \\
\hline f. NGO's & 58 & 14 & 2 & 26 & - & - & - & - \\
\hline g. The Ministry of Education & 30 & 35 & 14 & 21 & - & - & - & - \\
\hline h. The local community & 9 & 47 & 35 & 9 & 7 & 36 & 51 & 4 \\
\hline i. Other schools in the municipality & 30 & 42 & 7 & 21 & 35 & 40 & 17 & 5 \\
\hline j. Others & 44 & 5 & 5 & 47 & 23 & 27 & 12 & 24 \\
\hline
\end{tabular}

School directors are also often involved, as well as teachers and parents. In $51 \%$ of municipalities in Norway and 35\% in Latvia, the local community was involved in deciding the fate of the school.

In Norway, as mentioned before, the levels of social capital are higher. Not surprisingly, we find that the community is more active in trying to influence the decision on school closure: in $54 \%$ of municipalities, the community was very active and $29 \%$ - quite active.

In comparison, in Latvia in $16 \%$ of municipalities, the community was very active and in $63 \%$ - quite active. Overall, the results show that various stakeholders are involved in decision-making as regards to the future of rural schools, and the local communities play an important role, too.

In Latvia, the two groups most actively trying to keep the school open are teachers and parents, while the groups supporting their closure are mainly local politicians and, sometimes, municipal administration. In 33\% of cases, there was no support for closure of the school from anyone at the municipality. Thus, it required the interference of the Ministry of Science and Education (Table 7).

In Norway, the groups trying to maintain the school are usually local politicians, parents, and the local community. The closure was opposed by the municipal administration, other local politicians, and, sometimes, the director of the school. Thus, a crucial difference is that in Norway, there is more support for maintaining the rural schools from at least some local politicians, the civil society organisations-both parents and pupils, and the local community in general are more active than in Latvia in trying to prevent the closure of schools.

In part, the relatively weaker involvement of different stakeholders in trying to preserve schools in Latvia is explained by the fact that they agreed that the school cannot be maintained.

When asked whether discussions about the possible school closure were characterised by conflict in the municipality or the affected community, in Latvia, $29 \%$ of the municipalities note that there were no conflicts as there was a large agreement about the decision; $52 \%$ note that there were discussions and different opinions but little conflict, and only $19 \%$ agree that there was inched a conflict about this issue in the affected community or even the whole municipality. In Norway, by contrast, in $36 \%$ of cases, there was a conflict in the affected community and in $12 \%$ of cases-in the whole community. 
TABLE 7 . Involvement of local actors (\%)

\begin{tabular}{lllll}
\hline \hline & \multicolumn{2}{c}{$\begin{array}{c}\text { Were Actively Trying to Keep } \\
\text { the School Open }\end{array}$} & Supported Closure \\
& Latvia & Norway & Latvia & Norway \\
\hline Director of the school & 37 & 15 & 14 & 32 \\
Teachers & 53 & 36 & 7 & 15 \\
Parents/parents' organisation & 49 & 79 & 2 & 20 \\
Pupils/pupils' organisation & 12 & 27 & 0 & 5 \\
Local politicians & 12 & 72 & 42 & 70 \\
Municipal administration & 2 & 1 & 28 & 76 \\
NGO's/civil society & 0 & 21 & 2 & 2 \\
Local community & 28 & 52 & 7 & 10 \\
Others & 5 & 5 & 2 & 2 \\
No-one & 7 & 9 & 33 & 1 \\
\hline \hline
\end{tabular}

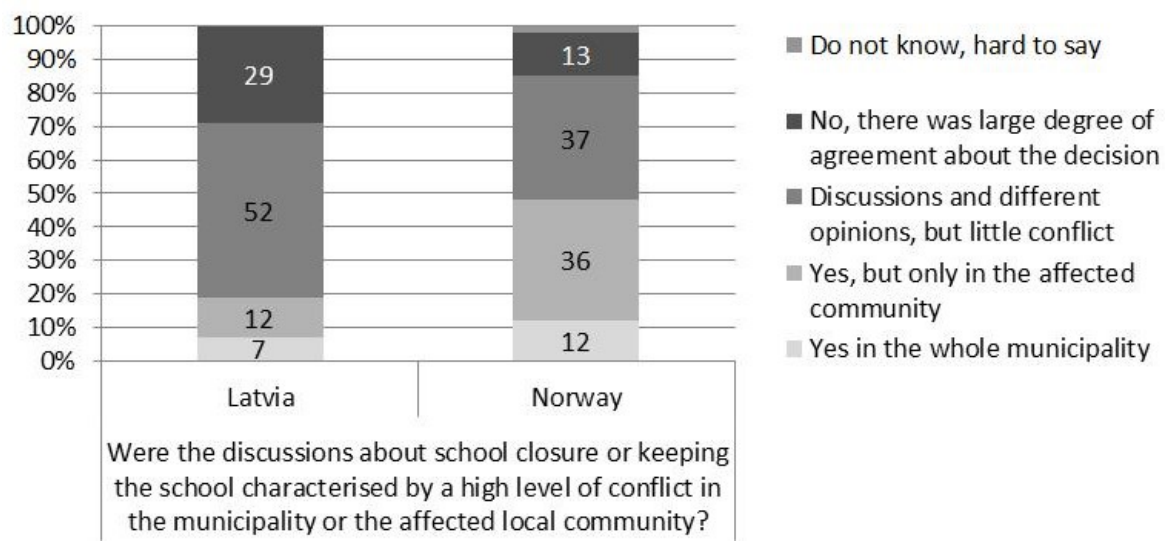

FIGURE 2 . Conflicts in the community due to possible closure of a school (\%)

The analysis shows that when the school closure was discussed, the school was less likely to be closed when teachers, local politicians, (in NO) municipal administration or (in LV) directors got involved and when the society was actively trying to influence the decision. In cases where the community was more active, the school was rarely (27-29\%) closed anyway. It had a significantly higher chance of being maintained (Table 8).

TABLE 8. Involvement of local actors and the fate of schools (\%)

\begin{tabular}{lllllll}
\hline \hline \multirow{7}{*}{ Latvia } & & $\begin{array}{l}\text { It was } \\
\text { Closed }\end{array}$ & $\begin{array}{l}\text { It was } \\
\text { Maintained }\end{array}$ & $\begin{array}{l}\text { It was } \\
\text { Merged with } \\
\text { Another School }\end{array}$ & $\begin{array}{l}\text { It was } \\
\text { Replaced by } \\
\text { a New School }\end{array}$ & Other \\
& Very active & 29 & 29 & 29 & 0 & 14 \\
& Quite active & 59 & 4 & 33 & 0 & 4 \\
& Not active & 33 & 17 & 33 & 0 & 17 \\
& Very active & 27 & 35 & 19 & 8 & 10 \\
& Quite active & 32 & 20 & 28 & 4 & 16 \\
& Not active & 44 & 22 & 33 & 0 & 0 \\
\hline \hline
\end{tabular}




\section{CONCLUSION AND DISCUSSION}

This study reveals that the perspectives on merging classes and closing schools in different countries can differ-depending on the historical, social, and economic context. Surveyed municipalities in Norway are distinctly leaning towards consolidation strategy and see many benefits to it. Municipalities in Latvia clearly support their small schools and see keeping them open as crucial. There are several reasons for that:

- If the nearest school has been closed, families move away with their children to other municipalities (usually to big cities or emigrate from Latvia). It results in economic loss for municipality;

- If the nearest school has been closed, families choose schools near their workplace, which often is other municipality (usually in big cities or regional centres). Due to mutual payments between municipalities, it results in economic loss for municipality;

- Small rural schools often are targeting the problem of early school leavers from rural areas (NEETs) more effectively than schools in cities.

This study clearly shows that a school in a rural community is much more than simply an educational institution; it plays a much more important role in the development of rural communities that needs to be taken into account when deciding on the fate of these schools. In Latvia, a common fear among municipalities and, even more, representatives of schools is that without a school, there will be no people in the community, no economic development, and no work for teachers. These concerns are not shared by stakeholders in Norway. Future studies need to explore why the general evaluation of the impact of consolidating the school network on learning/teaching and social environment in Latvia and Norway so radically differs.

The survey reveals many similarities between the processes of school consolidation in Latvia and Norway, but also important differences. Norway has a strong, established civil society and channels of local democracy, and the decision on school closure was rarely influenced by national authorities. In Latvia, the participation of schools and local communities in decision-making is limited by information gap and capacity to use available information. A very important reason of information gap is uncertainty about the possible reforms because territorial and educational reforms are almost permanent in Latvia, and the policies are often changing. The problem of representatives of schools and municipalities is also a fear to do something wrongly. This is a consequence of previous hierarchical relations and mutual lack of trust. A more timid reaction to school closure in Latvia could also partly be explained by the fact that there is a shortage of knowledge on possible alternatives to the closing of schools, and a lack of human capital in rural areas because of difficulties to attract qualified teachers and education experts to rural areas.

In case of both Norway and Latvia, we find support for the endogenous development theory, yet a higher level of social capital in Norway that has contributed to more local mobilisation and higher level of conflict in Norway in cases where a school closure was considered. In Latvia, the impact of local community on many municipalities is weak because of lack of skills to cooperate and to formulate common goals, as well as the lack of clear vision of development at all governance. The analysis suggests that mobilisation matters for outcome. Despite the society being more concerned about the possible effect of the school closures, more schools were closed in Latvia than in Norway. Part of the reason, the analysis suggests, was a more active involvement of the local community. 


\section{LIMITATION AND RECOMMENDATIONS}

It is important for the development of rural areas that different stakeholders are willing to cooperate to find a compromise: a national education ministry is looking for measures to save resources, politicians (both at national and municipal level) do not want to make unpopular decisions, and schools are fighting for survival. At the moment, in the context of uncertainty and poverty, very often broader vision of possibilities to look for solutions for the problems of community is missing (discussion of alternatives is very limited).

\section{ACKNOWLEDGEMENTS}

The research leading to these results has received funding from the EEA/Norwegian Financial Mechanism 2009-2014 under Project Contract no NFI/R/2014/014.

\section{REFERENCES}

Autti, Outi, and Eeva Kaisa Hyry-Beihammer. 2014. School closures in rural Finnish communities. Journal of Research in Rural Education 29, no. 1: 1-17.

Baldock, David, Janet Dwyer, Philip Lowe, Jan-Erik Petersen, and Neil Ward. 2001. Development: Towards a sustainable integrated rural policy in Europe. URL: https://goo.gl/KrEGhP (accessed December 15, 2016).

Central Statistical Bureau (CSB). 2015. Databases of central statistical bureau. ISG02. URL: https://goo.gl/UrtYVG (ac- cessed July 06, 2015).

Ana Belen S. Cuyugan, Gina E. Agus, Daniel D. Dasig Jr, Myrna A. Nidea, Eleonora E. Claricia, Mary Ann B. Taduyo, and Edmongino J. Camacho, 2017. In aid of community policy and framework development: A sustainable integrated commu- nity advancement program. Journal of Advanced Research in Social Sciences and Humanities 2, no. 2: 87-95.

DOI: $10.26500 /$ jarssh-02-2017-0202

Latvijas Sabiedriskie Mediji (LSM). 2015. LSM infografika: Vispārējā izglïtība skaiț̣os. URL: https://goo.gl/FbRVCS (ac- $\quad$ cessed December 12, 2015).

Long, Ann, and Jan Domue van der Ploeg. 1994. Endogenous development: Practices and perspectives.

URL: https://goo.gl/1ZiF9r (accessed December 16, 1994).

Lowe, Philip, Jonathan Murdoch, and Neil Ward. 1995. Networks in rural development: Beyond exogenous and endogenous models. In Beyond modernisation: The impact of endogenous rural development, eds., Jan Douwe Van der Ploeg and Gert Van Dijk: 87-106. Assen, NL: Uitgeverij Van Gorcum.

Marsden, Terry. 2009. Mobilities, vulnerabilities and sustainabilities: Exploring pathways from denial to sustainable rural development. Sociologia Ruralis 49, no. 2: 113-131. DoI: 10.1111/j.1467-9523.2009.00479.x

Nagler, Paula, and Wim Naudé. 2013. Non-farm entrepreneurship in rural Africa: Patterns and determinants. Forschungstitut zur Zukunft der Arbeit Institute for the Study of Labor, Bonn, DE.

Owusu. 2016. Collaborative knowledge management: Examining the challenges in the rural banking industry in the eastern region of Ghana. International Journal of Humanities, Arts and Social Sciences 2, no. 3: 111-120.

DOI: 10.20469 /ijhss.2.20005-3

Ray, Christopher. 2001. Culture economies: A perspective on local rural development in Europe. Centre for Rural Econ- omy. Department of Agricultural Economics and Food Marketing, University of Newcastle, Newcastle upon Tyne, UK.

Ray, Christopher. 2006. Neo-endogenous rural development in the EU. In Handbook of rural studies; 278-291. London, UK: Sage Publications. DOI: 10.4135/9781848608016.n19

Ray, Christopher. 1998. Culture, intellectual property and territorial rural development. Sociologia Ruralis 38, no. 1: 3-20. DOI: $10.1111 / 1467-9523.00060$

Shucksmith, Mark. 2000. Exclusive countryside? Social inclusion and regeneration in rural areas. New York, NY: Joseph Rowntree Foundation.

Teng, Quoquab, Hussin, and Mohammad. 2016. Re-defining sustainable development values and its facets based on developcountry perspective. Journal of Advances in Humanities and Social Sciences 1, no. 2: 1-13. 
DOI: $10.20474 /$ jahss 2.1.1

Van der Ploeg, Jan Douwe, and Gert Van Dijk. 1995. Beyond modernization: The impact of endogenous rural develop- ment. Assen, NL: Uitgeverij Van Gorcum.

Woolcock, Michael, and Deepa Narayan. 2000. Social capital: Implications for development theory, research, and policy.

The World Bank Research Observer 15, no. 2: 225-249. D0I: 10.1093/wbro/15.2.225

— This article does not have any appendix. — 